\title{
Characterization of bottom ashes from coal pulverized power plants to determine their potential use feasibility
}

\author{
E. MENÉNDEZ ${ }^{1}$, A. M. ÁlVARO ${ }^{1,2}$, C. ARGIZ ${ }^{1,3}$, J. L. PARRA ${ }^{4}$, A. MORAGUES ${ }^{3}$ \\ 'Instituto de Ciencias de la Construcción "Eduardo Torroja" (IETCC - CSIC) \\ 2ETSI Telecomunicación - UPM \\ ${ }^{3}$ ETSI Caminos, Canales y Puertos - UPM \\ ${ }^{4}$ ETSI Minas - UPM
}

\begin{abstract}
The disposal of coal by products represents environmental and economical problems around the world. Therefore, the reuse and valorisation of this waste has become an important issue in the last decades. While high-value construction products containing fly ash were developed and its use is actually totally accepted as an addition to cement, the use of the bottom ash as supplementary cementitious material has not been allow. This paper examines the chemical and physical properties of fly ashes and bottom ashes from two different coal power plants in order to compare them and analyse the potential feasibility of bottom ash as cement replacement. The mechanical properties of cement mortars made with different percentages of both ashes were also study. The results obtained showed similar chemical composition of both kinds of ashes. The compressive strength values of mortars with $10 \%$ and $25 \%$ of cement replacement (at 28 days) were above the limits established in European standards and there were not significant differences between fly ash and bottom ash from both origins.
\end{abstract}

Keywords: bottom ash, chemical properties, microstructure, addition to cement, raw materials, mechanical properties.

Caracterización de cenizas de fondo procedentes de centrales térmicas de carbón para determinar su viabilidad de uso

La eliminación de subproductos del carbón supone problemas ambientales y económicos en todo el mundo por lo que la reutilización y valorización de los mismos se ha convertido en un tema importante en las últimas décadas. Mientras que las cenizas volantes se han utilizado en aplicaciones de alto valor y se han desarrollado productos de construcción en los que se ha utilizado esta ceniza como adición al cemento, no se ha sido permitido la utilización de la ceniza de fondo como en cementos. Este artículo examina las propiedades químicas y físicas de las cenizas volantes y de fondo procedentes de dos centrales termoeléctricas con el objetivo de compararlas y analizar la potencial utilización de la ceniza de fondo como adición al cemento. Se han estudiado también las propiedades mecánicas de morteros de cemento fabricados con distintos porcentajes de ambas cenizas como sustitución del cemento. Los resultados obtenidos mostraron que las ambos tipos de cenizas tenían una composición química similar. Los valores de resistencia a compresión a 28 días de los morteros con un $10 \%$ y $25 \%$ de porcentaje de sustitución estaban dentro de los límites permitidos en la normativa Europea y no había diferencias significativas entre las cenizas volantes y de fondo procedentes de ambas centrales térmicas.

Palabras clave: ceniza de fondo, propiedades químicas, microestructura, adición al cemento, materias primas, propiedades mecánicas.

\section{INTRODUCTION}

Coal ash from pulverized coal - fired power plants represents a big amount of total residues in many countries, especially when low quality carbon is used, producing not only lack of space but also important environmental and health problems. The ashes collected from pulverized coal fired furnaces are fly ash (FA) and bottom ash (BA) and they are produced due to an incomplete combustion of coal. FA constitutes around the $80 \%$ of total ashes produced and it is composed of fine particles that remain in suspension in the air stream. BA constitutes around the $20 \%$ of total ashes and it is composed of bigger particles, which drop, melt, conglomerate and vitrify in the bottom of the furnace [1-2]. Both kind of ashes contain trace metals which could be leached to water and damage the aquatic ecosystem [3]. In Europe, it was generated 41 million tonnes of coal ashes in 2009 and around half of them were landed into landfills [4].

Although around half of the total amount of FA generated in Europe is disposed in landfills or it is not used in high - value industrial products, there are some high - value applications to reuse this waste [1-2; 4]. The reutilization of FA as Supplementary Cementitious Material (SCM) in the construction industry is an example of high - value application utterly accepted [5] which enhances cement properties [6-7] and reduces both the amount of raw materials and the $\mathrm{CO}_{2}$ emitted when cement is manufactured.

Contrary to FA, coal BA has not been seen as a high value SCM in construction industry; BA has been disposed or used as low cost replacement for more expensive sand in the 
production of concrete blocks and in many countries, it has been used as a base in road construction [1-2]. However, this point of view has been changing in the last years. Cheriaf et al. [8] have evidenced the pozzolanic activity of ground coal BAs with lime at 28 days and have suggested the use of BA as acting addition in cementitious materials. This fact has been also observed by Jaturapitakkul [9] et al. and also by Kurama and Kaya [10], who have concluded that the addition of BA as partial cement replacement up to $10 \%$ could improve the mechanical properties of concrete. There have been different experiments mixing BA with other additions. Kula et al. [11] have found that the replacement of Portland cement (PC) by colemanite waste, BA and FA generally results to a better performance in the compressive strength of the PC paste. Kula et al. [12] also have investigated the use of tincal ore waste in cement and they found that using BA as partial replacement of tincal ore waste obtaining a better performance of concrete that using FA. Canpolat et al. [13] have studied the effects of the replacement of zeolite and BA or FA in different proportions in $\mathrm{PC}$, observing that the majority of the cements studied showed a compressive strength greater than the CEM I 42.5 cement. Recently, Argiz et al. [14] have studied the effect on physical and mechanical properties of mortars with different proportions of FA and BA as partial replacement of cement up to $35 \%$ and they have concluded that there are not technological differences between both ashes. Despite these investigations, the European standards not allow the use of BA as addition to cement at present.

The present paper investigates the feasibility of using BA as partial replacement of cement focusing on the Spanish and European standards, and studying the influence of the quality of coal. BA and FA were collected from two power plants burning coals of different qualities. Then, ashes were characterised and used as cement replacement in cementitious materials, studying and testing their mechanical properties.

\section{EXPERIMENTAL}

The current investigation involved characterising coal ashes and analysing mechanical properties of cementitious materials containing different proportions of these ashes in order to determine its potential feasibility.

\subsection{Characterization of coal ashes}

In this study, two Spanish thermal power plants burning different quality of coal were selected. The power plants were named $\alpha$ and $\beta$. Power plant $\alpha$ burns coal from South Africa $(90 \%)$ and Colombia (10\%) while power plant $\beta$ uses an indigenous Spanish coal whose FA contains more organic matter.

FA and BA were supplied from both power plants. Consequently, four types of ashes were examined. The designation of the different ashes is presented in Table I. Before testing them, BAs were grinding in order to obtain a granulometry similar than cement.

TABle I. Designation OF ASHES

\begin{tabular}{|c|c|c|}
\hline Type of ash & Power plant & Designation \\
\hline \multirow{2}{*}{ Fly Ash } & $\alpha$ & FA- $\alpha$ \\
\cline { 2 - 3 } & $\beta$ & FA- $\beta$ \\
\hline \multirow{2}{*}{ Bottom Ash } & $\alpha$ & BA- $\alpha$ \\
\cline { 2 - 3 } & $\beta$ & BA- $\beta$ \\
\hline
\end{tabular}

\subsubsection{CHEMICAL ANALYSIS}

The chemical composition of the ashes was determined by using $\mathrm{X}$ - ray fluorescence spectrometer (Bruker S8 Tiger equipment). The content of Lost on Ignition (LOI) was determined using the method in UNE - EN 196 - 2 [15] but the ashes were burnt during $1 \mathrm{~h}$. The content of $\mathrm{CaO}$ reactive

TABLE II. CHEMICAL COMPOSITION OF FLY AND BOTTOM ASH

\begin{tabular}{|c|c|c|c|c|c|c|c|}
\hline Ash & $\mathrm{SiO}_{\mathbf{2}}(\boldsymbol{\%})$ & $\begin{array}{c}\text { Reactive } \mathrm{SiO}_{\mathbf{2}} \\
\mathbf{( \% )}\end{array}$ & $\mathrm{Al}_{\mathbf{2}} \mathrm{O}_{\mathbf{3}}(\boldsymbol{\%})$ & $\mathrm{Fe}_{\mathbf{2}} \mathrm{O}_{\mathbf{3}} \mathbf{( \% )}$ & $\mathrm{CaO}(\boldsymbol{\%})$ & $\begin{array}{c}\text { Reactive CaO } \\
\mathbf{( \% )}\end{array}$ & L.O.I. (\%) \\
\hline FA- $\alpha$ & 46,84 & 33,98 & 26,66 & 4,72 & 5,55 & 7,5 & 3,63 \\
\hline FA- $\beta$ & 39,57 & 30,98 & 24,81 & 3,43 & 5,18 & 3,0 & 9,14 \\
\hline BA- $\alpha$ & 48,12 & 34,30 & 25,55 & 5,86 & 7,07 & 8,3 & 1,85 \\
\hline BA- $\beta$ & 48,34 & 38,68 & 19,46 & 8,96 & 6,44 & 3,5 & 1,55 \\
\hline
\end{tabular}

TABLE III. MiNOR ELEMENTS OF FLY AND BOTTOM ASH

\begin{tabular}{|c|c|c|c|c|}
\hline Element $(\%)$ & FA- $\alpha$ & FA- $\beta$ & BA- $\alpha$ & BA- $\beta$ \\
\hline $\mathrm{TiO}_{2}$ & 1,500 & 0,830 & 1,500 & 1,000 \\
\hline $\mathrm{MgO}$ & 1,330 & 1,290 & 1,280 & 1,800 \\
\hline $\mathrm{P}_{2} \mathrm{O}_{5}$ & 1,030 & 0,850 & 0,960 & 0,490 \\
\hline $\mathrm{K}_{2} \mathrm{O}$ & 0,500 & 0,520 & 0,440 & 1,420 \\
\hline $\mathrm{SO}_{3}$ & 0,370 & 0,600 & 0,150 & 0,100 \\
\hline $\mathrm{Na}_{2} \mathrm{O}$ & 0,170 & 0,220 & 0,140 & 0,710 \\
\hline $\mathrm{ZrO}_{2}$ & 0,055 & 0,040 & 0,060 & 0,039 \\
\hline $\mathrm{MnO}$ & 0,039 & 0,039 & 0,052 & 0,080 \\
\hline $\mathrm{V}_{2} \mathrm{O}_{3}$ & 0,036 & 0,018 & 0,029 & 0,038 \\
\hline $\mathrm{Cr}_{2} \mathrm{O}_{3}$ & 0,028 & 0,020 & 0,035 & 0,029 \\
\hline $\mathrm{ZnO}$ & 0,016 & 0,016 & 0,080 & 0,012 \\
\hline
\end{tabular}


was determined in accordance with UNE - 196 - 2 [15]. The main components and other chemical parameters are presented in Table II while minor components are shown in Table III.

In general, the FA and the BA from each power plant have similar compositions, except in the amount of calcium, iron, magnesium and chromium content, which is slightly higher in BAs.

The content of LOI limits the use of a FA as a cement addition due to possible future durability problems in cementitious materials. It is well known that higher values of LOI content in cement mortars produce higher damage due to frost ice [6].

A maximum value of $9 \%$ of LOI content in FA is established in the European standard UNE - EN 197 - 1 [16]. The LOI content of all ashes is under this limit value except in FA- $\beta$, which is on the edge. The relative high LOI content in FA- $\beta$ sample may be explained by the lower quality of the coal burned in this power plant, which contains more organic matter. However, the BA- $\beta$ sample has a similar LOI content that the BA- $\alpha$ sample and in any case lower than both FA samples examined.

The content by weight of $\mathrm{CaO}$ reactive in FAs categorise them into two types according to European standard UNE - 197 - 1 [16]. Siliceous FAs have less than $10 \%$ by weight of $\mathrm{CaO}$ reactive while calcareous FAs contain upper values of $\mathrm{CaO}$ reactive. In accordance with this classification, the FAs studied are siliceous ashes. By analogy, it can be said that BAs investigated are siliceous ashes too. It was also observed that ashes from power plant $\alpha$ have a mayor content of $\mathrm{CaO}$ reactive than ashes from power plant $\beta$.

\subsubsection{MINERAL PHASES}

The main crystalline phases of coal ashes were identify by X-ray diffractogram technique (Fig. 1). These main phases were quartz $\left(\mathrm{SiO}_{2}\right)$ and mullite $\left(\mathrm{Al}_{4} \mathrm{Si}_{2} \mathrm{O}_{10}\right)$, as well as anorthite $\left(\mathrm{CaAl}_{2} \mathrm{Si}_{2} \mathrm{O}_{8}\right)$ in bottom ashes. The quartz/mullite ratio was higher in BAs than FAs, probably due to the presence of anorthite in BAs. While FA- $\beta$ had a greater proportion of mullite than FA- $\alpha$, BA- $\beta$ had a minor proportion of mullite than BA- $\alpha$ maybe due to the higher content of anorthite in BA from $\beta$.

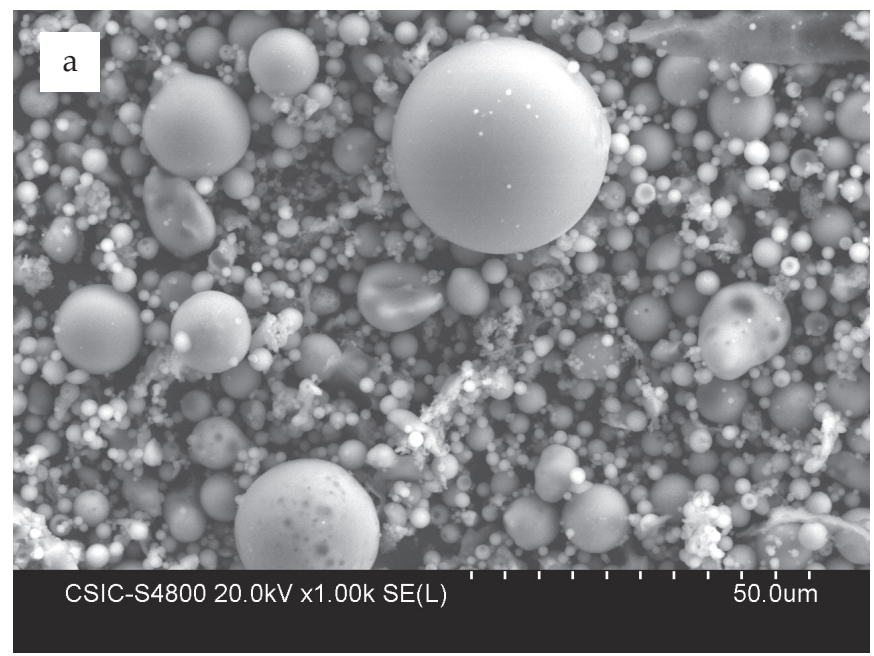

Figure 2. Micrograph SEM of fly ashes a) FA- $\alpha$ and b) FA- $\beta$

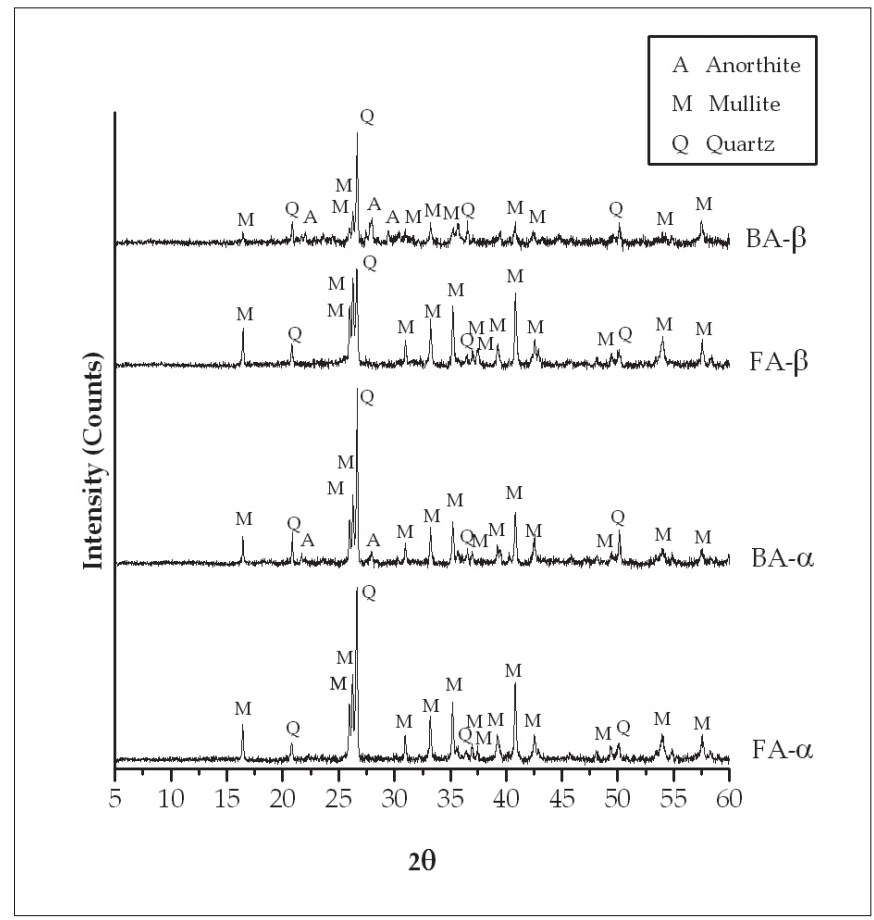

Figure 1. X-ray diffractogram of coal ashes.

\subsubsection{MICROSTRUCTURE}

The microstructure of coals ashes was analysed by scanning electron microscopy (SEM). While FAs were shaped by spherically particles of around $10 \mu \mathrm{m}$ (Fig. 2), BAs were irregular and higher particles around $30 \mu \mathrm{m}$ (Fig. 3), after grinding. This difference can be explained by different steep of the process where they are generated, the different quality of coals [1] and the grinding process realized to BAs in order to obtain a similar granulometry than cement.

\subsubsection{SPECIFIC SURFACE AREA}

The specific surface area of ashes plays an important role in their pozzolanic properties and hence in the mechanical properties of cementitous materials manufactured with them. The specific surface area of ash particles was measured by Blain permeability method described in European standard UNE - EN 196 - 6 [17] for cements.

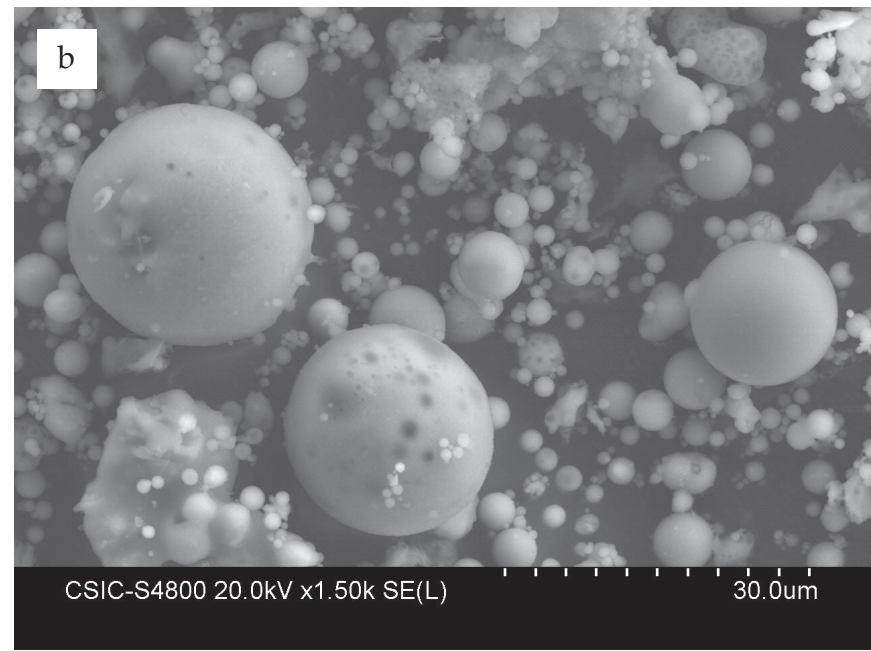




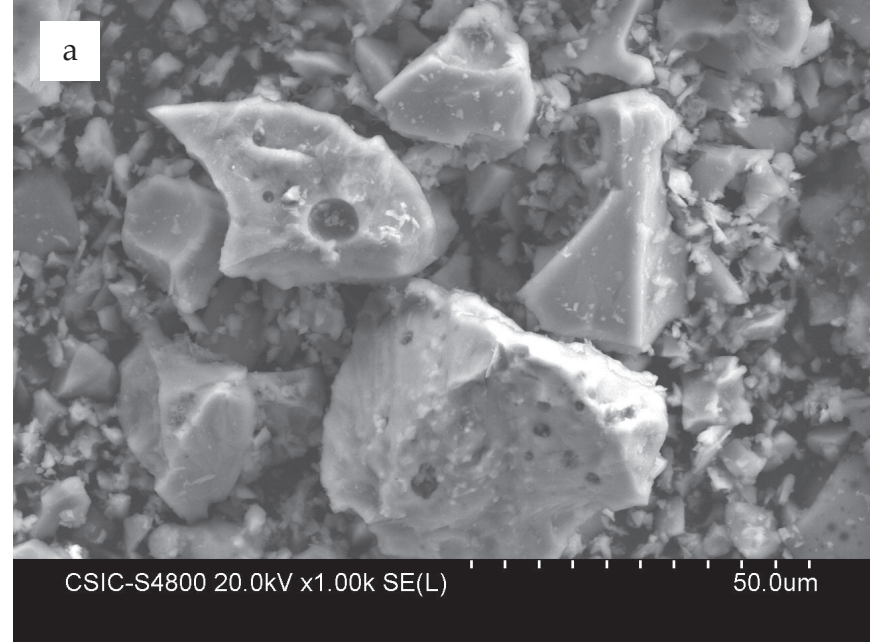

Figure 3. Micrograph SEM of bottom ashes a) BA- $\alpha$ and b) BA- $\beta$.

This method involves comparing the test sample with a reference cement sample.

Although BAs were grinded, FAs had a greater surface area than BAs because of FAs particles are smaller than BAs particles, as it was explained before. Comparing between the two power plants, coal ashes from power plant $\beta$, had a specific surface area greater than coal ashes from power plant $\alpha$.

\subsubsection{DENSITY}

The density of coal ash particles was measured by a pycnometer. Densities of particles were similar each other except to FA- $\alpha$ density which was appreciable lower than others were.

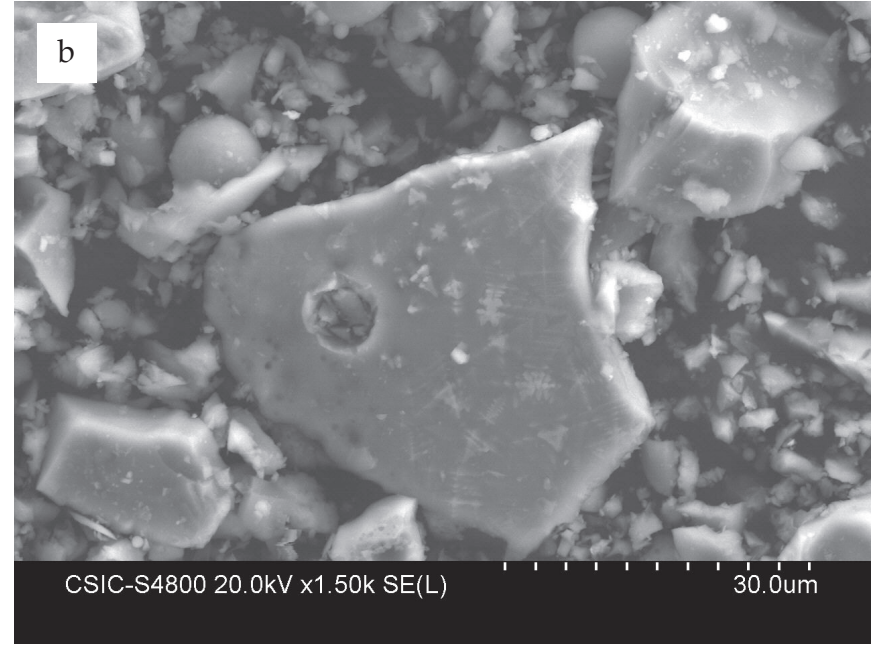

TABLE IV. SPECIFIC SURFACE AREA AND DENSITY OF ASHES

\begin{tabular}{|c|c|c|}
\hline Ash & $\begin{array}{c}\text { Specific surface area } \\
\left(\mathbf{c m}^{2} / \mathbf{g}\right)\end{array}$ & Density $\mathbf{( \mathbf { k g } / \mathbf { m } ^ { 3 } )}$ \\
\hline FA- $\alpha$ & 3976 & 2,25 \\
\hline FA- $\beta$ & 4668 & 2,62 \\
\hline BA- $\alpha$ & 3463 & 2,64 \\
\hline BA- $\beta$ & 4223 & 2,58 \\
\hline
\end{tabular}

\subsubsection{POZZOLANIC ACTIVITY}

The pozzolanic activity is the ability of a material to react with calcium hydroxide and water to form calcium silicate and calcium aluminates compounds, which are able to develop

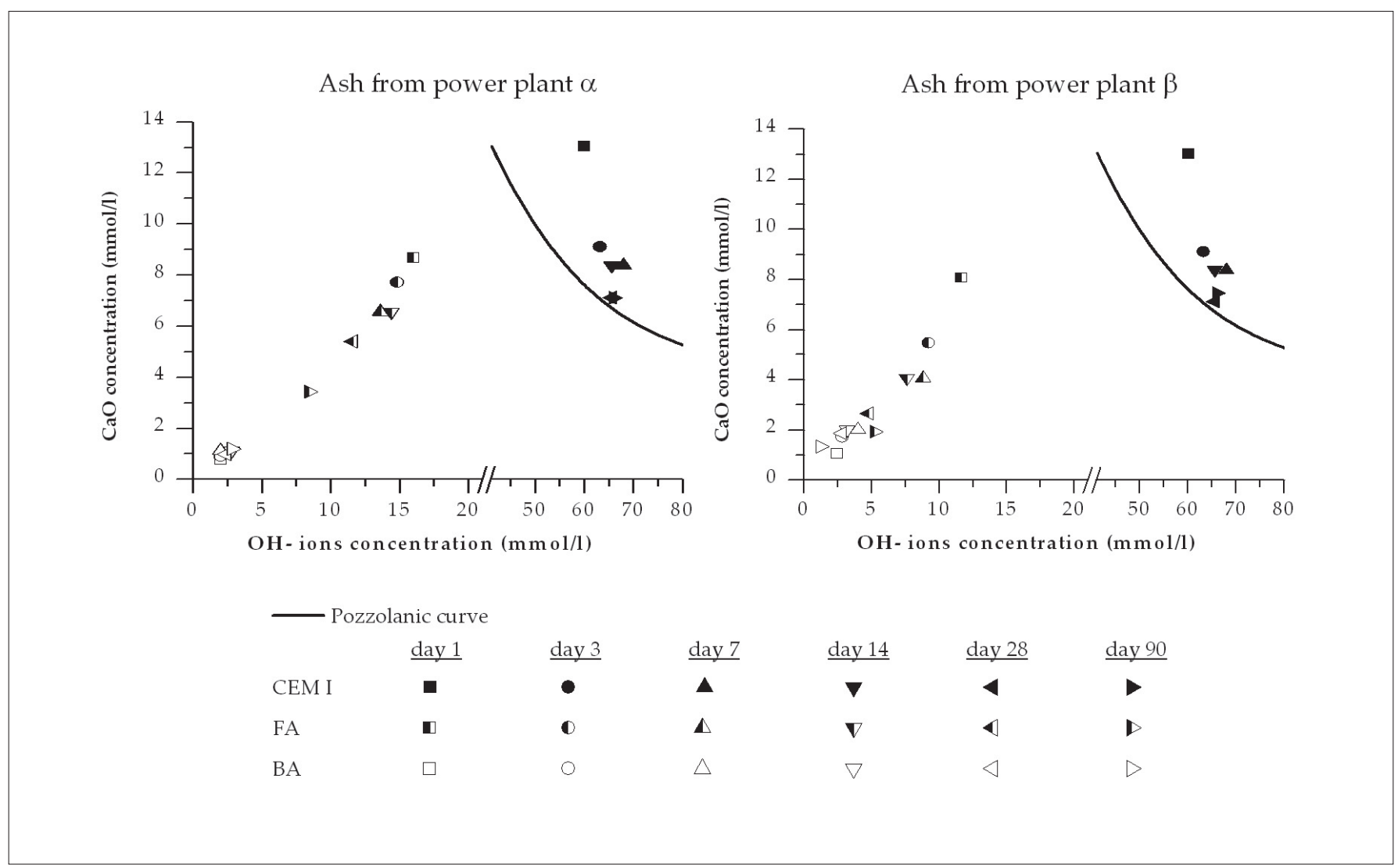

Figure 4. Pozzolanic activity of cement and coal ash. 
strength. The pozzolanic activity was tested using the method described in the European standard UNE - EN 196 - 5 [18]. This method consists on measuring the ion calcium concentration of an aqueous solution containing ashes during a specific period, expressing it as calcium hydroxide. The amount of ion calcium able to saturate a solution with the same alkalinity is also measured. Providing the amount of calcium able to saturate the solution is lower than the theoretical amount of saturation, the ashes will have pozzolanic character.

Since the use of additions modify the kinetic reaction of cement [19] and the degree of pozzolanic activity is an important factor for the development of strength at later ages [20], the test was performed at 1, 3, 7, 14, 28 and 90 days in order to evaluate the evolution of this property. It can be observed that both FA and BA had a pozzolanic character indicating that all the ashes are pozzolanic. On the other hand, CEM I did not show pozzolanic character because this kind of cement is not pozzolanic. Through time, it was observed that the $\mathrm{CaO}$ content decreased similarly than the solution alkalinity when FA was tested. In the case of BA, the $\mathrm{CaO}$ content and the solution alkalinity did not show appreciative changes during time (Fig. 4).

\subsection{Mechanical properties of cement mortars}

The strength's minimum requirements of cement mortars in Spain are specify in the Spanish Cement Reception Instruction (RC-08) [5]. In this paper, the strength of mortar specimens with different cement replacement were tested in order to verify the minimum requirement and to compare the behaviour of different additions.

\subsubsection{DESIGN OF CEMENT MIXTURES}

Cement mixtures made of different proportions of coal ash as cement replacement were designed. Percentages of $0 \%$,
$10 \%, 25 \%$ and $35 \%$ were selected corresponding to cements CEM I, CEM II/A, CEM II/B and CEM IV/A, respectively. There were cements made of additions $100 \%$ of FA- $\alpha, 100 \%$ of FA- $\beta, 100 \%$ of BA- $\alpha$ and $100 \%$ of BA- $\beta$. As $80 \%$ of total ashes produced in a power plant corresponds to FA and $20 \%$ to BA, two mixtures of additions consisting of $80 \%$ of FA- $\alpha$, plus $20 \%$ of BA- $\alpha$ and $80 \%$ of FA- $\beta$ plus $20 \%$ of BA- $\beta$ were also selected (Table V). All the cement mixtures were prepared with cement type CEM I 42.5.

\subsubsection{SPECIMEN PREPARATION}

In order to evaluate the mechanical properties and porosity of mortars containing the cement mixtures designed, four specimens of each cement mixture were prepared according to the specifications described in the standard UNE - EN 196 -1 [21]. The specimens were prismatic of $40 \mathrm{~mm} \times 40 \mathrm{~mm} \times$ $160 \mathrm{~mm}$, manufactured according to the standard mentioned and curing in moisture chamber $\left(20,0 \pm 1,0^{\circ} \mathrm{C}\right.$ y $\left.90 \% \mathrm{HR}\right)$ during $24 \mathrm{~h}$. After unmolding, specimens were covered with water until the test. The mechanical test was realised at 28 days.

\subsubsection{POROSITY OF MORTARS}

One of the specimens prepared was used to determine the porosity of cement mortar mixtures at 28 days of curing. The standard PrUNE - 83980 was used, which involves measuring the weight of the specimen under water - saturated and then completely dry. An increased in porosity was observed as cement replacement increased (Fig. 5). Cement mortar mixture manufacture with coal ash from power plant $\alpha$ had lower porosity (13\%-15\%) than those with coal ash from $\beta(14 \%-16 \%)$. Moreover, cement mortars with $10 \%$ of cement replacement from $\alpha$ had similar porosities than reference cement mortar (CEM I), independently of the type of ash.

TAble V. Cement Mixtures

\begin{tabular}{|c|c|c|c|c|c|c|}
\hline & CEM I $(\%)$ & $\begin{array}{l}\text { FA- } \alpha \\
(\%)\end{array}$ & $\begin{array}{c}\text { BA- } \alpha \\
(\%)\end{array}$ & $\begin{array}{l}\text { FA- } \beta \\
(\%)\end{array}$ & $\begin{array}{l}\text { BA- } \beta \\
(\%)\end{array}$ & Cement type corresponding to $\mathrm{RC}-08$ \\
\hline CEM I & 100 & 0 & 0 & 0 & 0 & CEM I \\
\hline $10 \mathrm{FA}-\alpha$ & 90 & 10 & 0 & 0 & 0 & \multirow{6}{*}{ CEM II / A } \\
\hline 10 FBA- $\alpha$ & 90 & 8 & 2 & 0 & 0 & \\
\hline $10 \mathrm{BA}-\alpha$ & 90 & 0 & 10 & 0 & 0 & \\
\hline $10 F A-\beta$ & 90 & 0 & 0 & 10 & 0 & \\
\hline $10 \mathrm{FBA}-\beta$ & 90 & 0 & 0 & 8 & 2 & \\
\hline $10 \mathrm{BA}-\beta$ & 90 & 0 & 0 & 0 & 10 & \\
\hline $25 \mathrm{FA}-\alpha$ & 75 & 25 & 0 & 0 & 0 & \multirow{6}{*}{ CEM II / B } \\
\hline $25 \mathrm{FBA}-\alpha$ & 75 & 20 & 5 & 0 & 0 & \\
\hline $25 B A-\alpha$ & 75 & 0 & 25 & 0 & 0 & \\
\hline $25 F A-\beta$ & 75 & 0 & 0 & 25 & 0 & \\
\hline 25 FBA- $\beta$ & 75 & 0 & 0 & 20 & 5 & \\
\hline $25 \mathrm{BA}-\beta$ & 75 & 0 & 0 & 0 & 25 & \\
\hline $35 \mathrm{FA}-\alpha$ & 65 & 35 & 0 & 0 & 0 & \multirow{6}{*}{ CEM IV / A } \\
\hline 35 FBA- $\alpha$ & 65 & 28 & 7 & 0 & 0 & \\
\hline $35 \mathrm{BA}-\alpha$ & 65 & 0 & 25 & 0 & 0 & \\
\hline $35 F A-\beta$ & 65 & 0 & 0 & 35 & 0 & \\
\hline 35 FBA- $\beta$ & 65 & 0 & 0 & 28 & 7 & \\
\hline $35 \mathrm{BA}-\beta$ & 65 & 0 & 0 & 0 & 25 & \\
\hline
\end{tabular}



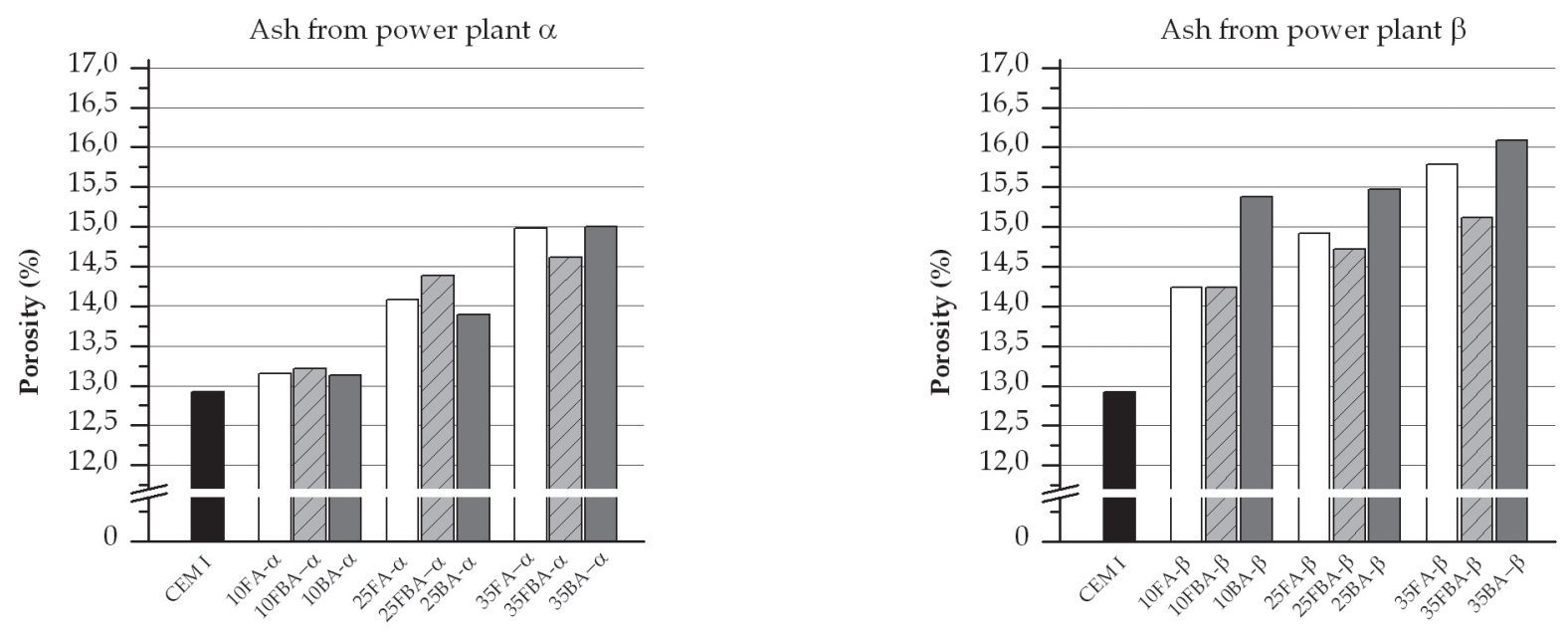

Figure 5. Porosity of mortars at 28 days of curing.
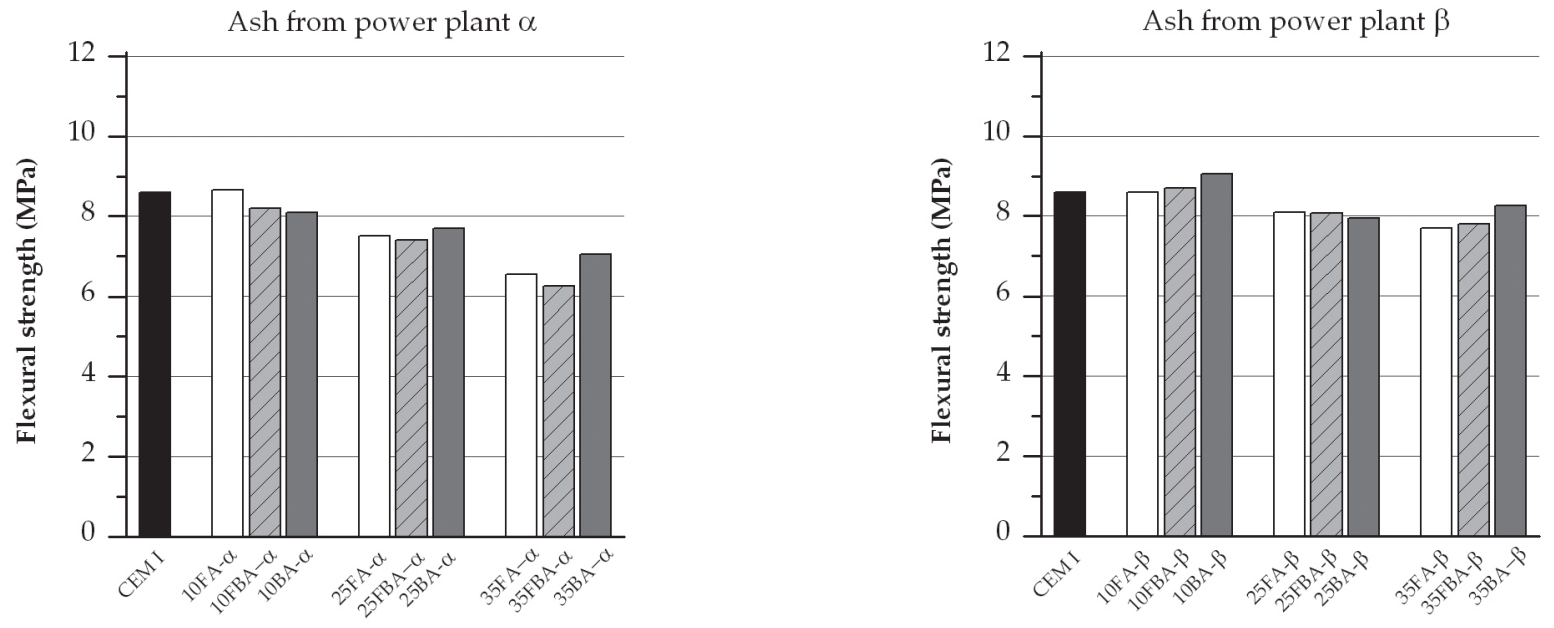

Figure 6. Flexural strength of mortars.

\subsubsection{FLEXURAL STRENGTH}

The relationship between the flexural strength and replacement percentage of cement was studied (Fig. 6). The flexural strength of specimens made of $10 \%$ of cement replacement was similar to the flexural strength of reference specimen made of CEM I. It was also observed that the flexural strength decreased slightly as replacement percentage increased. This effect was less significant when ashes from power plant $\beta$ were used. For each cement replacement percentage, the flexural strength of specimens made of BA was similar or even slightly higher than those specimens made of FA.

\subsubsection{COMPRESSIVE STRENGTH}

The relationship between compressive strength and replacement percentage of cement was studied (Fig. 7). The compressive strength of specimens with $10 \%$ of cement replacement was significant higher than the minimum requirement of $42,5 \mathrm{MPa}$ because they were similar or even higher than compressive strength of reference specimen made of CEM I. Similar to the flexural strength, the compressive strength of specimens decreased as replacement percentage increased. This behaviour was in accordance with Hanehara et al. [22], who confirmed that the reaction of FA decrease with the increased of cement replacement, and with other authors that obtained a better performance of mortars with lower cement replacement [9-10; 14].

Despite this, mortars with $10 \%$ of cement replacement largely meet the limit requirement and those with $25 \%$ of replacement precisely met this limit. It is well know that an adequate grinding of ashes enhances the mechanical properties of mortars [8], thus the compressive strength of specimens with $35 \%$ of cement replacement could be improved by grinding the ashes to achieve the minimum requirements.

The differences between FA and BA were not significant, especially when large amounts of ashes were used. For each cement replacement percentage, the compressive strength of specimens made of BA was similar than those specimens made of FA. 

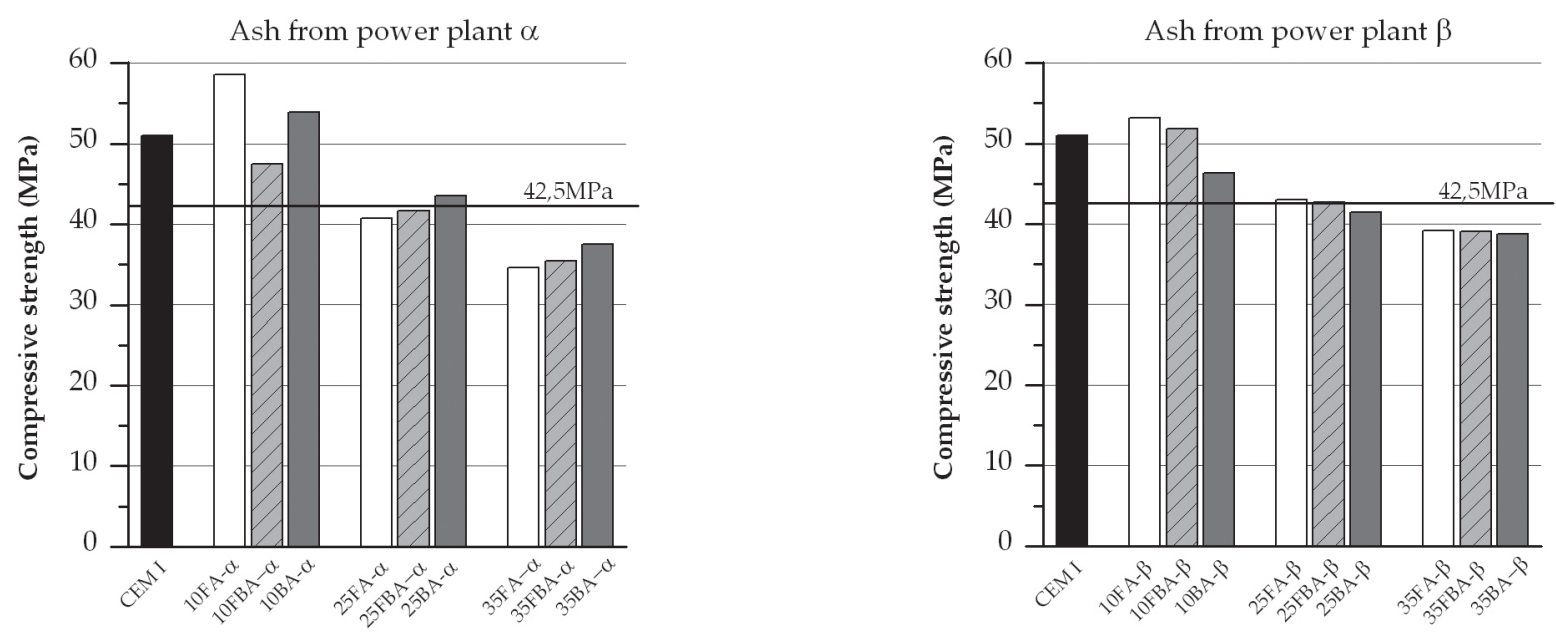

Figure 7. Compressive strength of mortars.

\section{DISCUSSION}

The potential relation between the pozzolanic character of the ashes with their physical and chemical properties were carefully studied. The pozzolanic parameter used to quantify the pozzolanic character was the sum of the amount of $\mathrm{CaO}$ and $\mathrm{OH}^{-}$obtained in the pozzolanic test. This pozzolanic parameter is presented proportional to the size of the sphere in Fig. 8 and it was considered that the pozzolanic character increased as this parameter decreased. The physical properties analysed were specific surface area and density. The chemical properties selected were the $\mathrm{LOI}$ and the sum of $\mathrm{SiO}_{2}, \mathrm{Al}_{2} \mathrm{O}_{3}$ and $\mathrm{Fe}_{2} \mathrm{O}_{3}$. The last one was chosen due to it is an important parameter referred in the European standard UNE - EN - 450 -1 [23]. A minimum of $70 \%$ of amount of $\mathrm{SiO}_{2}+\mathrm{Al}_{2} \mathrm{O}_{3}+\mathrm{Fe}_{2} \mathrm{O}_{3}$ is required when fly ashes are used as concrete addition.

Any clear relation was found when physical properties were correlated to the pozzolanic parameter. From each power plant, although FAs had a greater specific surface area, BAs had a higher pozzolanic character. Furthermore, the ashes studied had similar densities except to FA- $\alpha$, which was slightly lower. The different nature of ashes and the similar physical properties between the ashes might be the reason of the lack of relation.

However, an interesting relation was found when the pozzolanic parameter was correlated to the chemical properties of ashes. It was observed that pozzolanic character of ashes increased as the amount of $\mathrm{SiO}_{2}+\mathrm{Al}_{2} \mathrm{O}_{3}+\mathrm{Fe}_{2} \mathrm{O}_{3}$ increased and the amount of LOI decresed. This was true for all the ashes studied and was evidently for FA- $\beta$. FA- $\beta$ had the greater amount of LOI (around $9 \%$ ) and the lower amount of $\mathrm{SiO}_{2}+\mathrm{Al}_{2} \mathrm{O}_{3}+\mathrm{Fe}_{2} \mathrm{O}_{3^{\prime}}$ quite far from the other ashes presented. On the other hand, BAs had a content of LOI substantially lower than FAs and consequently a greater pozzolanic character.

The relation between the mechanical properties of cement mortars and the cement replacement percentage was carefully studied. Although compressive strength of specimens decreased with the increased of cement replacement, this decreased was sharper when FA was used instead BA or the mixture $\mathrm{FA}+\mathrm{BA}$. Therefore, the difference between compressive strength of mortars with $\mathrm{BA}$ or $\mathrm{BA}+\mathrm{FA}$ and mortars with the same percentage of FA, tended to minimised (Fig. 9). Therefore, mortars with a $35 \%$ of BA or BA+FA had a similar or higher compressive strength that mortars with $35 \%$
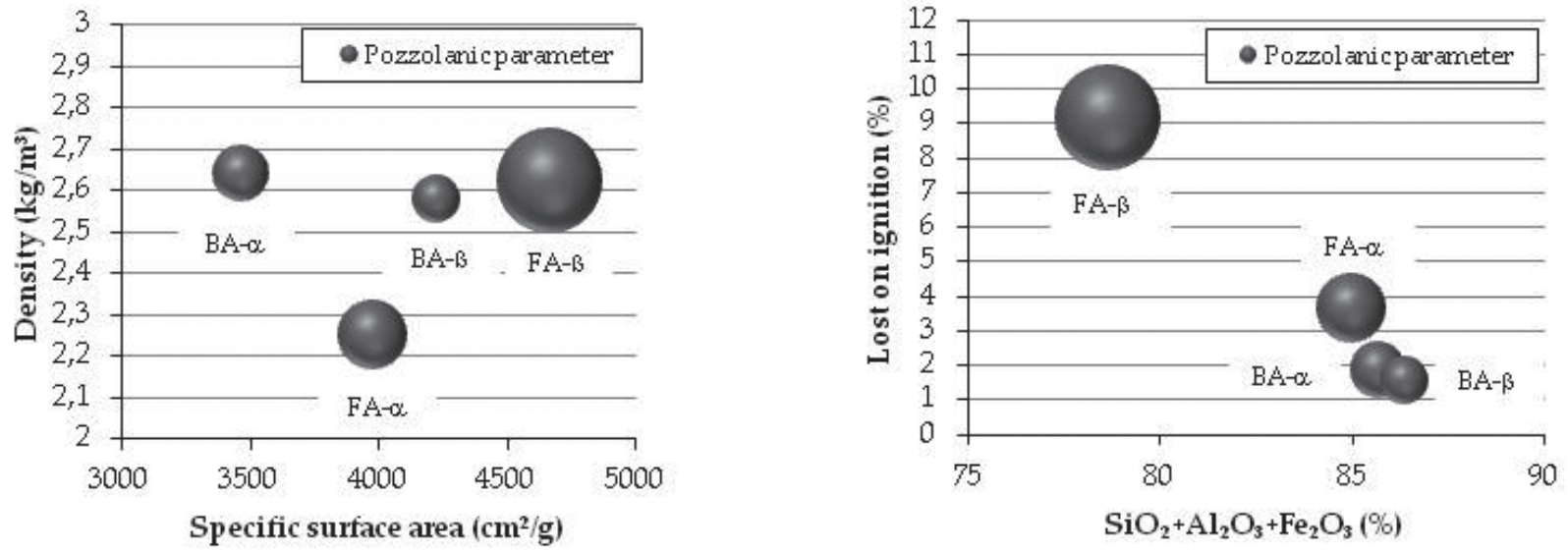

Figure 8. Relationship between the pozzolanic parameter and the physical or chemical properties of ashes. 

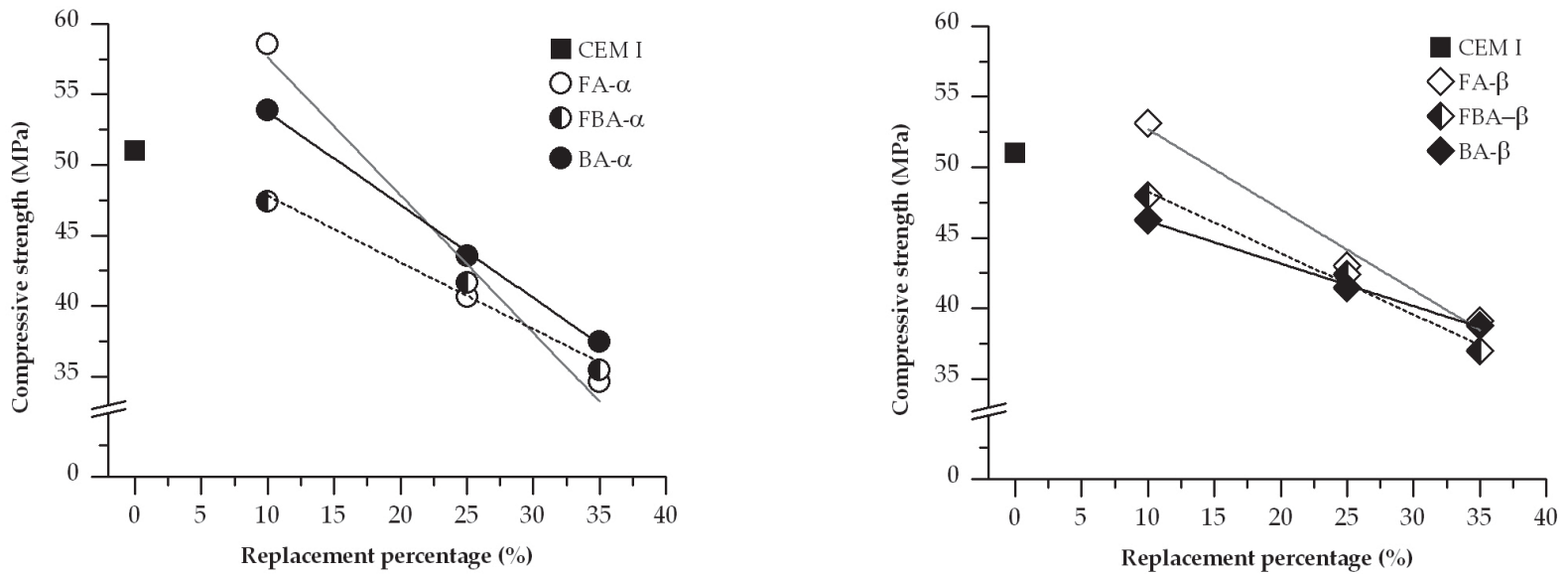

Figure 9. Relationship between compressive strength of mortars and cement replacement percentage.

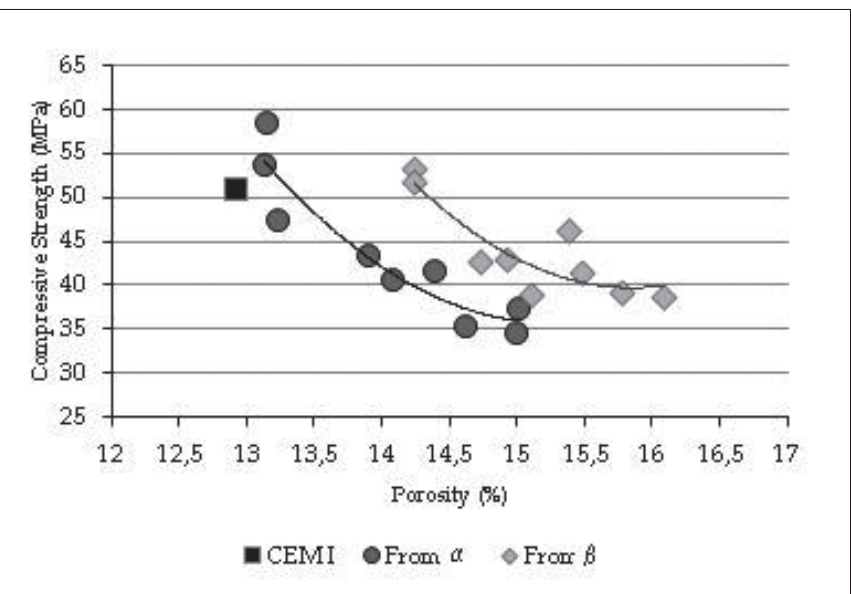

Figure 10. Relationship between porosity and compressive strength of mortars.

of FA, either $\alpha$ or $\beta$ ashes were used. This can be explained by the higher pozzolanic activity [20] and less LOI content that was observed in BAs instead of FA.

Moreover, when the mechanical properties of cement mortar mixtures were correlate to its porosity, interesting results were observed (Fig. 10). As porosity of cement mortar increased, its compressive strength decreased. The increased of porosity was also related to the amount of cement replacement, as was reported in the results section. As cement replacement increased, the porosity also increased. Therefore, as increased the amount of cement replacement, the porosity increased and then, the compressive strength decreased. Concerning to the power plant influence, at the same amount of porosity, mortars made of ashes from $\beta$ had higher compressive strength than mortars made with ashes from $\beta$.

\section{CONCLUSIONS}

- Bottom ashes from pulverized coal combustion power plants have a similar chemical composition than fly ashes except to iron, manganese and chromium, which are a bit higher.
- Although the morphology of bottom ashes is quite different from fly ashes, the specific surface area and density are similar between them.

- An adequate grinding of bottom ashes is essential to use this waste as an addition to cement because they are higher than fly ashes.

- The Lost on Ignition of bottom ashes is low even when its corresponding fly ashes have a higher content of LOI. This could have a benefit effect over frost damage properties of cementitious materials made of bottom ash.

- Bottom ashes have pozzolanic activity at earlier stages than fly ashes, fundamental property to develop strength in cementitious materials.

- Although mechanical properties decreased with the increased of cement replacement due to the increased of porosity, a substitution of $10 \%$ and $25 \%$ allow mortars to fulfil the minimums requirements specify in Spanish standards.

- When low percentages of ashes (10\%) were used, mortars with fly ash had a moderate better mechanical performance than mortars with BA. However, when higher percentages (25\% and $35 \%$ ) of ashes from the same power plant were used, irrelevant differences in mechanical properties were observed.

- The origin of ashes did not have a significant influence on the mechanical properties of mortars despite the different kind of coals used in the two power plants.

- According to the results obtained, the use of BA as partial cement replacement could be feasible, although durability properties and potential migration of heavy metals to the environment must be studied.

\section{BIBLIOGRAFY}

1. Siddique, R. (2010): Utilization of coal combustion by-products in sustainable construction materials. Resources Conservation and Recycling, 54(12), pp. 1060-1066.

2. Asokan, P., Saxena, M., \& Asolekar, S. R. (2005): Coal combustion residuesenvironmental implications and recycling potentials. Resources Conservation $\mathcal{E}$ Recycling, 43, pp. 239-262.

3. Izquierdo, M., \& Querol, X. (2012): Leaching behaviour of elements from coal combustion fly ash: An overview. International Journal of Coal Geology, 94(0), pp. 54-66. 
4. ECOBA (2009): Production and Utilisation of CCPs in 2009 in Europe. Disponible en: http:/ / www.ecoba.org/.

5. Real Decreto 956/2008, de 6 de junio, por el que se aprueba la instrucción para la recepción de cementos (RC-08). Boletín Oficial del Estado, 6 de junio de 2008, núm. 148, p.27794-27841.

6. Menéndez, E., Frutos, J. d., \& Andrade, C. (2009): Análisis no destructivo del estado de degradación en morteros bajo la acción de ciclos de hielo - deshielo. Boletín de la Sociedad Española de Cerámica y Vidrio, 48(5), pp. 223230.

7. Menéndez, E., \& Frutos, J. d. (2012): Generación y caracterización de microgrietas en materiales estructurales. Boletín de la Sociedad Española de Cerámica y Vidrio, 51(1), pp. 45-54.

8. Cheriaf, M., Rocha, J. C., \& Péra, J. (1999): Pozzolanic properties of pulverized coal combustion bottom ash. Cement and Concrete Research, 29(9), pp. 1387-1391.

9. Jaturapitakkul, C., \& and Cheerarot, R. (2003): Development of Bottom Ash as Pozzolanic Material. Journal of Materials in Civil Engineering, 15(1), pp. 48-53.

10. Kurama, H., \& Kaya, M. (2008): Usage of coal combustion bottom ash in concrete mixture. Construction and Building Materials, 22, pp. 1922-1928.

11. Kula, I., Olgun, A., Erdogan, Y., \& Sevinc, V. (2001): Effects of colemanite waste, cool bottom ash, and fly ash on the properties of cement. Cement and Concrete Research, 31(3), pp. 491-494

12. Kula, I., Olgun, A., Sevinc, V., \& Erdogan, Y. (2002): An investigation on the use of tincal ore waste, fly ash, and coal bottom ash as Portland cement replacement materials. Cement and Concrete Research, 32(2), pp. 227-232.

13. Canpolat, F., Yılmaz, K., Köse, M. M., Sümer, M., \& Yurdusev, M. A. (2004): Use of zeolite, coal bottom ash and fly ash as replacement materials in cement production. Cement and Concrete Research, 34(5), pp. 731-735.
14. Argiz, C., Menéndez, E., \& Sanjuán, M. A. (2013): Effect of mixes made of coal bottom ash and fly ash on the mechanical strength and porosity of Portland cement. Materiales de Construcción, 63, pp. 49-64.

15. UNE - EN 196 - 2 (2006): Methods of testing cement. Part 2: Chemical analysis of cement. Madrid: AENOR.

16. UNE - EN 197 - 1 (2011): Cement. Part 1: Composition, specifications and conformity criteria for common cements. Madrid: AENOR.

17. UNE - EN 196 - 6 (2010): Methods of testing cement. Part 6: Determination of fineness. Madrid: AENOR.

18. UNE - EN 196 - 5 (2011): Methods of testing cement. Part 5: Pozzolanicity tes for pozzolanic cement. Madrid: AENOR.

19. Menéndez, E., \& Frutos, J. d. (2011): Equivalencia entre medidas eléctricas y difracción de rayos $\mathrm{X}$ en la formación de fases cristalinas de pastas de cemento. Boletín de la Sociedad Española de Cerámica y Vidrio, 50(5), pp. 225234

20. Taylor, H. F. W. (1997): Cement Chemist. London: Thomas Telford.

21. UNE-EN 196-1 (2005): Methods of testing cement. Part 1: Determination of strength. Madrid: AENOR.

22. Hanehara, S., Tomosawa, F., Kobayakawa, M., \& Hwang, K. (2001): Effects of water/powder ratio, mixing ratio of fly ash, and curing temperature on pozzolanic reaction of fly ash in cement paste. Cement and Concrete Research, 31, pp. 31-39.

23. UNE-EN 450-1:2006 (2006): Fly ash for concrete. Part 1: Definition, specification and conformity criteria. Madrid: AENOR.

Recibido: 20/05/2013

Recibida versión corregida: 08/12/2013

Aceptado: 11/12/2013 